Supplementary Information

\title{
Direct Evidence of a Tryptophan Radical formed in a Concerted Electron Proton Transfer Reaction in Water
}

Prateek Dongare, Somnath Maji and Leif Hammarström*

Department of Chemistry - Ångström Laboratory, Uppsala University, Box 523, SE-751 20, Uppsala, Sweden

Leif.Hammarström@kemi.uu.se

\section{Table of contents}

1. List of Figures.

2. Experimental Section

2.1. General

2.2.Physical Measurements

2.3. Sample Preparation

2.4.Data Acquisition

3. Supporting Data

4. Kinetic analysis of a consecutive PTET or ETPT reaction for 2.

5. References

\section{List of Figures:}

Figure S1. Quenching of $\left[\mathrm{Ru}(\mathrm{bpy})_{3}\right]^{2+}[35 \mu \mathrm{M}]$ upon addition of $\left[\mathrm{Ru}\left(\mathrm{NH}_{3}\right)_{6}\right]^{3+}[40$ $\mathrm{mM}]$ as quencher employed in the quenching of linked systems.

Figure S2. Quenching of $\left[\mathrm{Ru}(\mathrm{bpy})_{3}\right]^{2+}$ luminescence upon addition of $\left[\mathrm{Ru}\left(\mathrm{NH}_{3}\right)_{6}\right]^{3+}$ [40 $\mathrm{mM}$ ] as quencher employed in the quenching of linked systems. The decay shows that the quenching in the absence of a tryptophan moiety is over within 43 ns.

Figure S3. The appearance and decay of Trp radical signal at $510 \mathrm{~nm}$ as a result of CEPT in 2 in presence of $\left[\mathrm{Ru}\left(\mathrm{NH}_{3}\right)_{6}\right]^{3+}[40 \mathrm{mM}]$. (pH 7.2, $0.5 \mathrm{mM}$ phosphate-borate buffer); the signal decay is due to irreversible dimerization of the radicals.

Figure S4. The appearance and decay of $\operatorname{Trp}^{\bullet} \mathrm{H}^{+}$radical cation at $570 \mathrm{~nm}$ as a result of ET followed by PT (ETPT) in 1 in presence of $\left[\mathrm{Ru}\left(\mathrm{NH}_{3}\right)_{6}\right]^{3+}[40 \mathrm{mM}]$. (pH 7.2, 0.5 $\mathrm{mM}$ phosphate-borate buffer). The deprotonation rate constant was obtained as $k_{\mathrm{PT}}=$ $2.51 \times 10^{6} \mathrm{~s}^{-1}$. 
Figure S5. The diminishing $\operatorname{Trp}^{\circ}$ signal at $510 \mathrm{~nm}$ and concomitant appearance of $\operatorname{Trp}^{\bullet} \mathrm{H}^{+}$at $570 \mathrm{~nm}$ in complex 1 upon addition of $\left[\mathrm{Ru}\left(\mathrm{NH}_{3}\right)_{6}\right]^{3+}[40 \mathrm{mM}]$ as quencher, for clarity 510 (blue) trace is multiplied by 5 . The sample was excited at $532 \mathrm{~nm}$ in $\mathrm{N}_{2}$ saturated $0.5 \mathrm{mM}$ phosphate-borate buffer at $\mathrm{pH}$ 7.2.

Figure S6. Overlaid transient absorption decay traces of complex 2, for clarity 510 (blue) and $450 \mathrm{~nm}$ traces (black) are multiplied by 5 . The data obtained upon addition of $\left[\mathrm{Ru}\left(\mathrm{NH}_{3}\right)_{6}\right]^{3+}[40 \mathrm{mM}]$ as quencher. The sample was excited at $532 \mathrm{~nm}$ in $\mathrm{N}_{2}$ saturated $0.5 \mathrm{mM}$ phosphate-borate buffer at $\mathrm{pH}$ 7.2.

Figure S7. Quenching of $\left[\mathrm{Ru}(\mathrm{bpy})_{3}\right]^{2+}$ upon addition of $\left[\mathrm{Ru}\left(\mathrm{NH}_{3}\right)_{6}\right]^{3+}[40 \mathrm{mM}]$ as quencher employed in the quenching of linked systems. The decay shows no noticeable spectroscopic signatures for $\operatorname{Trp}{ }^{\bullet}$ or $\operatorname{Trp}^{\bullet} \mathrm{H}^{+}$at $510 \mathrm{~nm}$ and $560 \mathrm{~nm}$, respectively in the absence of any linked tryptophan moiety.

Figure S8. Decay traces of 2 in Phosphate-borate buffer $(0.5 \mathrm{mM}, \mathrm{pH} 7.2)$ with $\left[\mathrm{Ru}\left(\mathrm{NH}_{3}\right)_{6}\right]^{3+}[40 \mathrm{mM}]$ as quencher at different $\mathrm{pH}$ 's.

Figure S9. Phosphate buffer dependence of $k_{\mathrm{obs}}$ for 2 and fit to the equation: $k_{\mathrm{obs}}=k_{\mathrm{w}}$ $+f_{\mathrm{b}}$ [buffer] $k_{\mathrm{b}}$ at $\mathrm{pH} 7$.

\section{Experimental Section}

2.1. General: All solvents and commercially supplied chemicals were reagent grade and used as received without further purification. Triethylamine (TEA), 2,2'-bipyridine (bpy), 4,4'-dimethyl-2,2'-bipyridine (4,4'-dmb), and $\mathrm{RuCl}_{3} \cdot 3 \mathrm{H}_{2} \mathrm{O}$ were purchased from Aldrich. Ammonium hexafluorophosphate was purchased from Fluka and (1H-Indol3-yl)methanamine was purchased from Novo Chemy Limited, China. Complexes 1 and 2 were prepared according to our previously reported procedures. ${ }^{1,2,3}$ The structures were confirmed by NMR and ESI-MS and elemental analysis.

2.2. Physical Measurements: ${ }^{1} \mathrm{H}-\mathrm{NMR}$ spectra were measured in $\mathrm{CD}_{3} \mathrm{CN}$ solvent using a JEOL $400 \mathrm{MHz}$ spectrometer at 293 K. HPLC-MS data were obtained using a Dionex UltiMate 3000 system on a Phenomenex Gemini C18 column (150 x $3.0 \mathrm{~mm}, 5 \mu \mathrm{m})$ coupled to a Thermo LCQ Deca XP Max with electrospray ionization. Solvents used 
for HPLC: $0.05 \% \mathrm{HCO}_{2} \mathrm{H}$ in $\mathrm{H}_{2} \mathrm{O}$ and $0.05 \% \mathrm{HCO}_{2} \mathrm{H}$ in $\mathrm{CH}_{3} \mathrm{CN}$. Elemental analysis (C, H, N) was performed by Analytische Laboratorien GmbH (Lindlar, Germany).

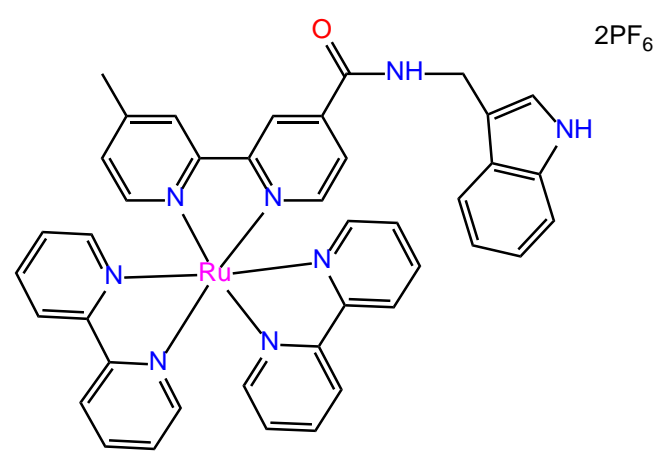

${ }^{1} \mathrm{H}$ NMR (400 MHz, acetonitrile-d $\left.\mathrm{d}_{3}\right) \delta=9.23$ (s, 1H), 8.74 (d, $\left.J=1.5 \mathrm{~Hz}, 1 \mathrm{H}\right), 8.47$ (d, $J=7.7$ Hz, 6H), $8.07-8.00$ (m, 5H), 7.81 (d, $J=5.9 \mathrm{~Hz}, 1 \mathrm{H}), 7.69-7.64$ (m, 5H), 7.53 (d, $J=5.8$ Hz, 1H), $7.42-7.32$ (m, 6H), 7.25 (d, $J=6.9 \mathrm{~Hz}, 1 \mathrm{H}), 7.15$ (t, $J=7.0 \mathrm{~Hz}, 1 \mathrm{H}), 7.05$ (t, $J=$ $7.0 \mathrm{~Hz}, 1 \mathrm{H}), 4.77$ (d, $J=5.5 \mathrm{~Hz}, 2 \mathrm{H}), 2.52$ (s, 3H). Elemental analysis calculated for $\mathrm{C}_{41} \mathrm{H}_{34} \mathrm{~F}_{12} \mathrm{~N}_{8} \mathrm{OP}_{2} \mathrm{Ru} \cdot 2 \mathrm{H}_{2} \mathrm{O}$ : C, 45.52; H, 3.54; N, 10.36. Found: C, 45.27; H, 3.52; N, 10.15 . ESI-MS(+): $\left[\mathrm{M}-2 \mathrm{PF}_{6}\right]^{2+}, \mathrm{m} / \mathrm{z}=377.65$, calcd: 377.92 .

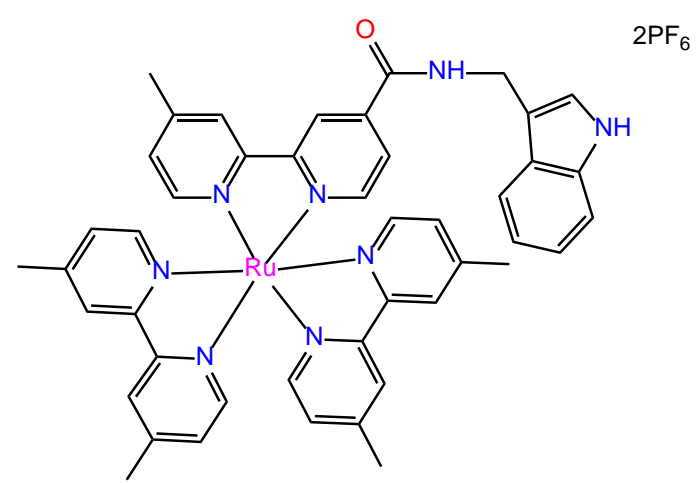

${ }^{1} \mathrm{H}$ NMR (400 MHz, acetonitrile- $\left.\mathrm{d}_{3}\right) \delta=9.24(\mathrm{~s}, 1 \mathrm{H}), 8.73(\mathrm{~s}, 1 \mathrm{H}), 8.44(\mathrm{~s}, 1 \mathrm{H}), 8.32(\mathrm{~s}, 4 \mathrm{H})$, $7.82(\mathrm{~d}, J=5.9 \mathrm{~Hz}, 1 \mathrm{H}), 7.68-7.61(\mathrm{~m}, 2 \mathrm{H}), 7.54-7.46(\mathrm{~m}, 6 \mathrm{H}), 7.41$ (d, $J=8.2 \mathrm{~Hz}, 1 \mathrm{H})$, $7.31(\mathrm{~d}, J=2.4 \mathrm{~Hz}, 1 \mathrm{H}), 7.24-7.17(\mathrm{~m}, 6 \mathrm{H}), 7.05$ (t, $J=7.5 \mathrm{~Hz}, 1 \mathrm{H}), 4.76$ (d, $J=5.6 \mathrm{~Hz}$, $2 \mathrm{H}), 2.51$ (s, $12 \mathrm{H}), 2.50$ (s, 3H). Elemental analysis calculated for $\mathrm{C}_{45} \mathrm{H}_{42} \mathrm{~F}_{12} \mathrm{~N}_{8} \mathrm{OP}{ }_{2} \mathrm{Ru}$ : C, 


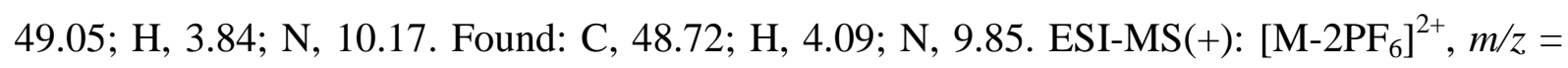
405.67, calcd: 405.98 .

\subsection{Sample Preparation}

The aqueous solutions were prepared using deionized water $(17 \mathrm{M} \Omega \mathrm{cm})$. Samples were degassed with $\mathrm{N}_{2}$ gas before and during the measurements. The solution under study contained $\sim 30 \mu \mathrm{M}$ of $\mathrm{Ru}$ complex and $5-200 \mathrm{mM}$ of $\mathrm{MV}^{2+}$ or $40 \mathrm{mM}$ of $\left[\mathrm{Ru}\left(\mathrm{NH}_{3}\right)_{6}\right]^{3+}$ as quencher. The buffer solution was prepared by mixing $\mathrm{NaH}_{2} \mathrm{PO}_{4}$ and $\mathrm{NaH}_{2} \mathrm{BO}_{3}$ (Sigma Aldrich 99\%) in deionized water. The $\mathrm{pH}$ was adjusted with $\mathrm{NaOH}(\mathrm{aq})$ and concentrated $\mathrm{HCl}$ prior to and during the data acquisition using a Methrom pH-meter (Micro electrode). Isotopic effect measurements were conducted using deuterium oxide (Sigma Aldrich, 99.9\%) as solvent by making necessary correction as described by Long. ${ }^{4}$

External quencher $\left[\mathrm{Ru}\left(\mathrm{NH}_{3}\right)_{6}\right]^{3+}$ (Alfa Aeser) was used as received and methylviologen dichloride hydrate (Aldrich, 98\%) was recrystallized from ethanol.

\subsection{Data Acquisition}

Optical absorption traces were measured on a Cary 5000 instrument from Varian before and after the experiments in order to verify that no sample degradation had occurred during irradiation. By optical absorption spectroscopy we also ensured that there are no significant absorbing impurities present in the samples.

For transient absorption measurements, optical excitation was afforded by an OPO (opotek) pumped by a frequency tripled Q-switched Nd:YAG laser (Quantel Brilliant B), delivering c.a. 7 ns pulses at $460 \mathrm{~nm}$ (с.а. $20 \mathrm{~mJ} /$ pulse). A pulsed Xenon lamp of an Applied Photophysics LKS60 setup provided analyzing light that was passed through $1 \times 1 \mathrm{~cm}$ quartz sample cuvette in a right-angle configuration and through a monochromator before hitting the P928 type photomultiplier. The PMT signal was converted and digitized using a HP Infinitum 
digital oscilloscope (2G samples/s). Transient absorption traces were generated from the raw data used the LKS60 software.

Transient absorption spectra were acquired on Spectra Physics Quanta-Ray system with a frequency tripled Q-switch Nd:YAG laser coupled with a MOPO to afford the pumping wavelength of $460 \mathrm{~nm}$ with $\sim 10 \mathrm{~ns}$ pulse duration and $10 \mathrm{~Hz}$ repetition rate. The pulse laser was also connected to a transient absorption detection system

(Edinburgh Instruments), equipped with a monochromator and a pulsed Xe arc lamp. Transient absorption of the sample was collected at right angle to the incoming laser beam by a Tektronix 500MHz digital oscilloscope coupled to a CCD camera to record transient absorption spectra. The output was processed with Edinburgh Instruments L900 software provided by the manufacturer. The raw data set was plotted and analyzed using origin 8.0 program (origin Lab Corporation). The error presented in this work is obtained from the standard deviation obtained upon fitting though an appropriate function. In general, each experiment is repeated at least three times to ensure the stability of the samples and reproducibility of the results. Kinetic data in the main paper is the average ( $\pm S \mathrm{SD}$ ) of at least 4 traces, each one generated by an average of 4-8 laser shots.

\section{Supporting Data}

Fig S1 shows that in the absence of an attached tryptophan moiety the decay of Ru bleach at $450 \mathrm{~nm}$ is identical to the emission at $600 \mathrm{~nm}$. In addition, once a quencher is added the extent of quenching of $* \mathrm{Ru}^{\mathrm{II}}$ is reflected in $600 \mathrm{~nm}$ emission trace and the only reaction observed is a recombination reaction. 


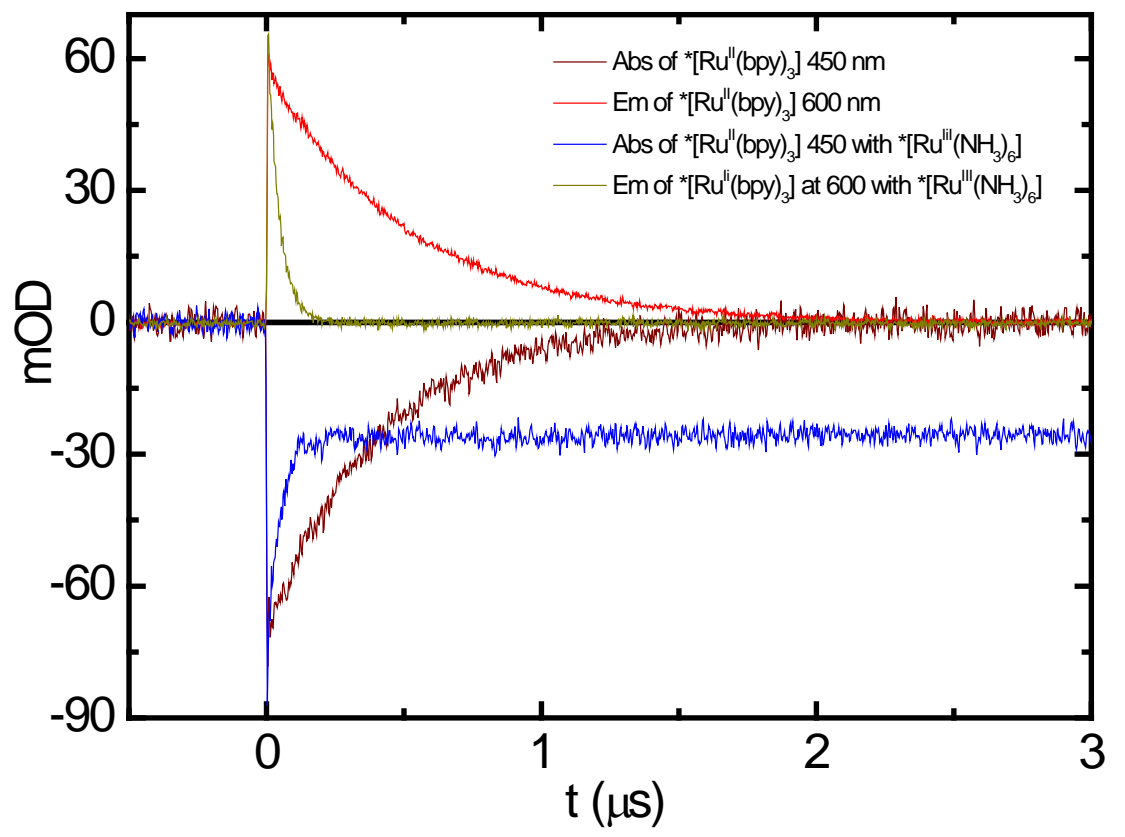

Figure S1. Quenching of $\left[\mathrm{Ru}(\mathrm{bpy})_{3}\right]^{2+}[35 \mu \mathrm{M}]$ upon addition of $40 \mathrm{mM}\left[\mathrm{Ru}\left(\mathrm{NH}_{3}\right)_{6}\right]^{3+}$ as quencher employed in the quenching of linked systems.

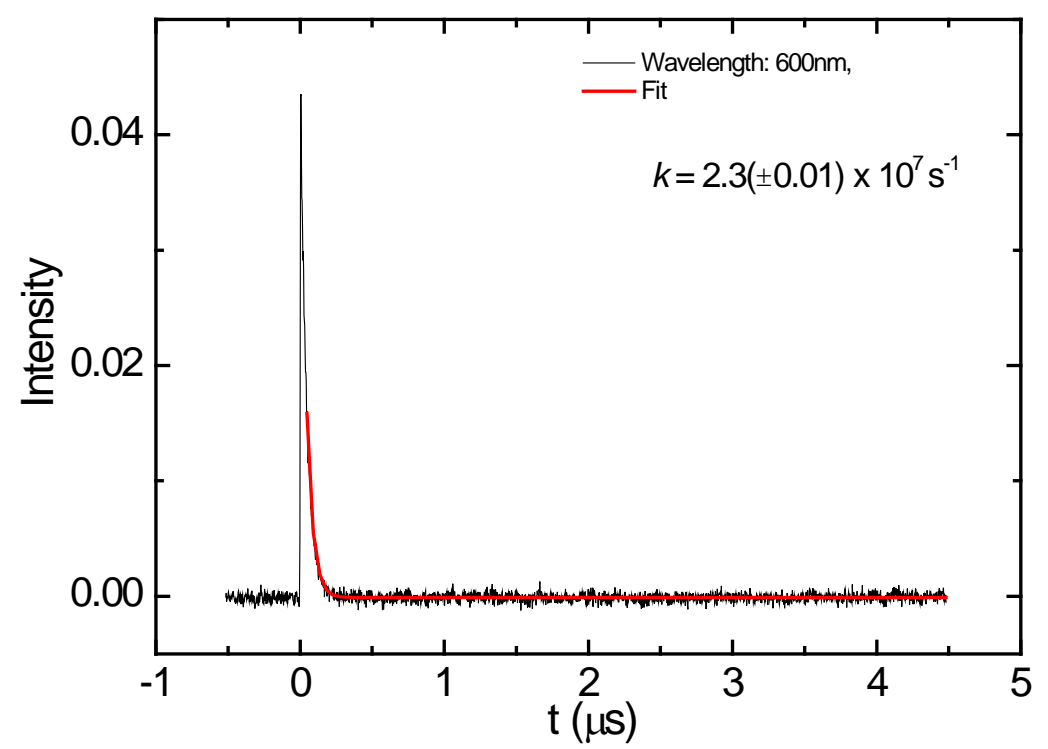

Figure S2. Quenching of $\left[\mathrm{Ru}(\mathrm{bpy})_{3}\right]^{2+}$ luminescence upon addition of $40 \mathrm{mM}\left[\mathrm{Ru}\left(\mathrm{NH}_{3}\right)_{6}\right]^{3+}$ as quencher employed in the quenching of linked systems. The decay shows that the quenching lifetime in absence of a tryptophan moiety $43 \mathrm{~ns}$. 


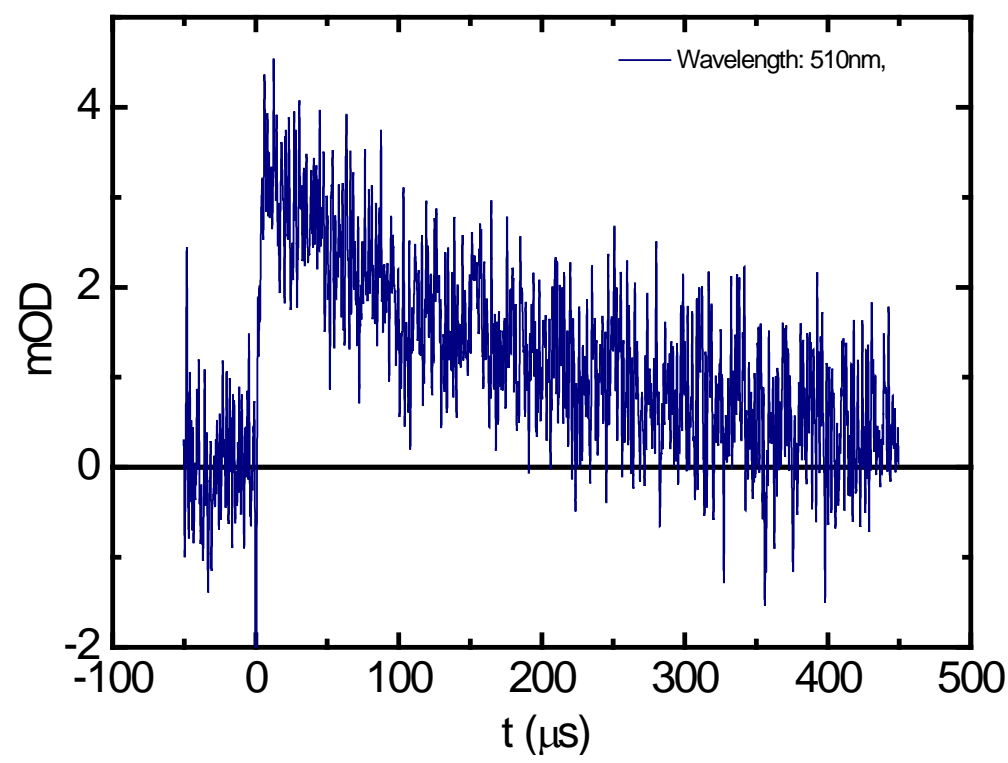

Figure S3. The decay of Trp ${ }^{\bullet}$ radical signal at $510 \mathrm{~nm}$ due to recombination with the reduced acceptor $\left[\mathrm{Ru}\left(\mathrm{NH}_{3}\right)_{6}\right]^{2+}$. Trp ${ }^{\bullet}$ was formed as a result of CEPT in $\mathbf{2}$ in presence of $40 \mathrm{mM}$ $\left[\mathrm{Ru}\left(\mathrm{NH}_{3}\right)_{6}\right]^{3+}$. (pH 7.2, $0.5 \mathrm{mM}$ phosphate-borate buffer); the signal decays with a $\mathrm{t}_{1 / 2}=90 \mu \mathrm{s}$.

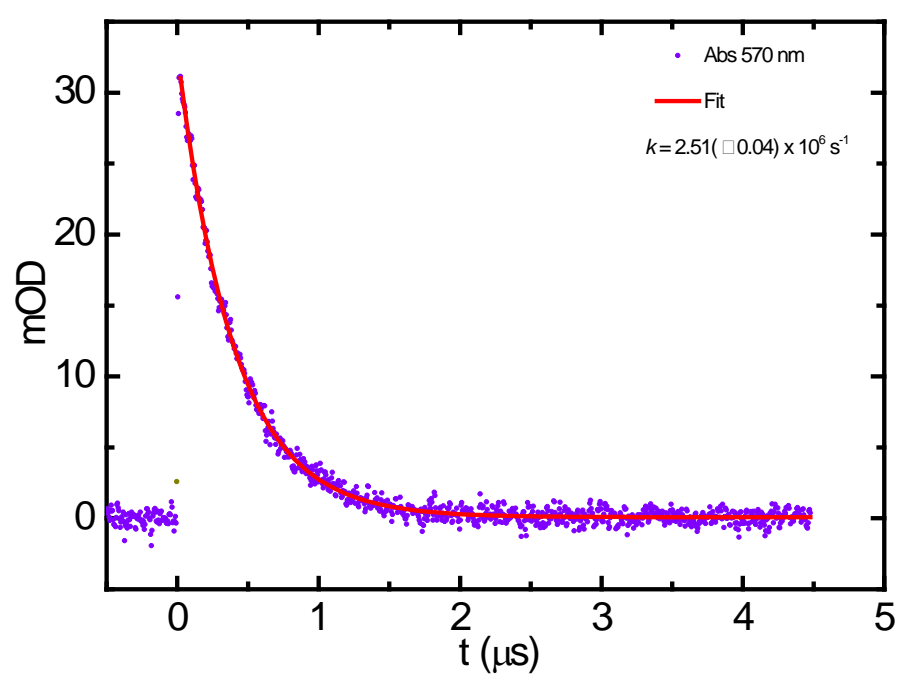

Figure S4. The decay of $\operatorname{Trp}^{\bullet} \mathrm{H}^{+}$radical cation at $570 \mathrm{~nm}$ by deprotonation. $\operatorname{Trp}^{\bullet} \mathrm{H}^{+}$was formed by ETPT in 1 in presence of $40 \mathrm{mM}\left[\mathrm{Ru}\left(\mathrm{NH}_{3}\right)_{6}\right]^{3+}$. (pH 7.2, $0.5 \mathrm{mM}$ phosphate-borate buffer). The deprotonation rate constant was obtained as $k_{\mathrm{PT}}=2.5 \times 10^{6} \mathrm{~s}^{-1}$. 


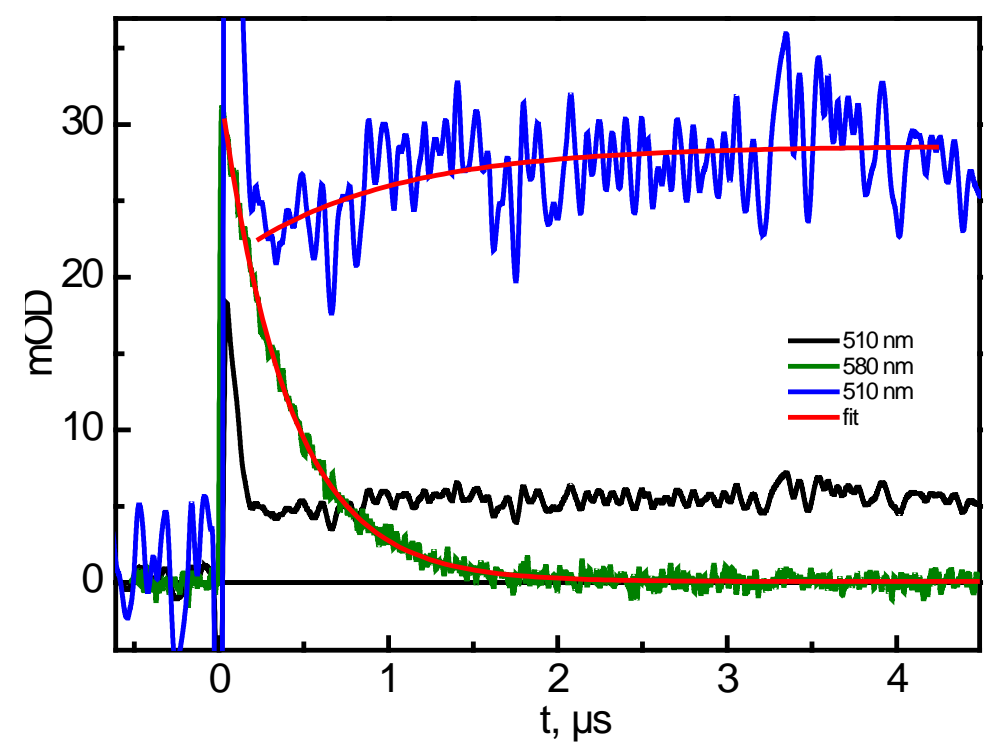

Fig S5. Decay of the $\operatorname{Trp}^{\bullet} \mathrm{H}^{+}$signal at $580 \mathrm{~nm}$ (green) and concomitant appearance of Trp ${ }^{\bullet}$ at $510 \mathrm{~nm}$ (black) in complex 1, for clarity the $510 \mathrm{~nm}$ signal is also multiplied by 5 (blue). The sample was excited at $532 \mathrm{~nm}$ in $\mathrm{N}_{2}$ saturated $0.5 \mathrm{mM}$ phosphate-borate buffer at $\mathrm{pH} 7.2$ with $40 \mathrm{mM}\left[\mathrm{Ru}\left(\mathrm{NH}_{3}\right)_{6}\right]^{3+}$ as quencher.

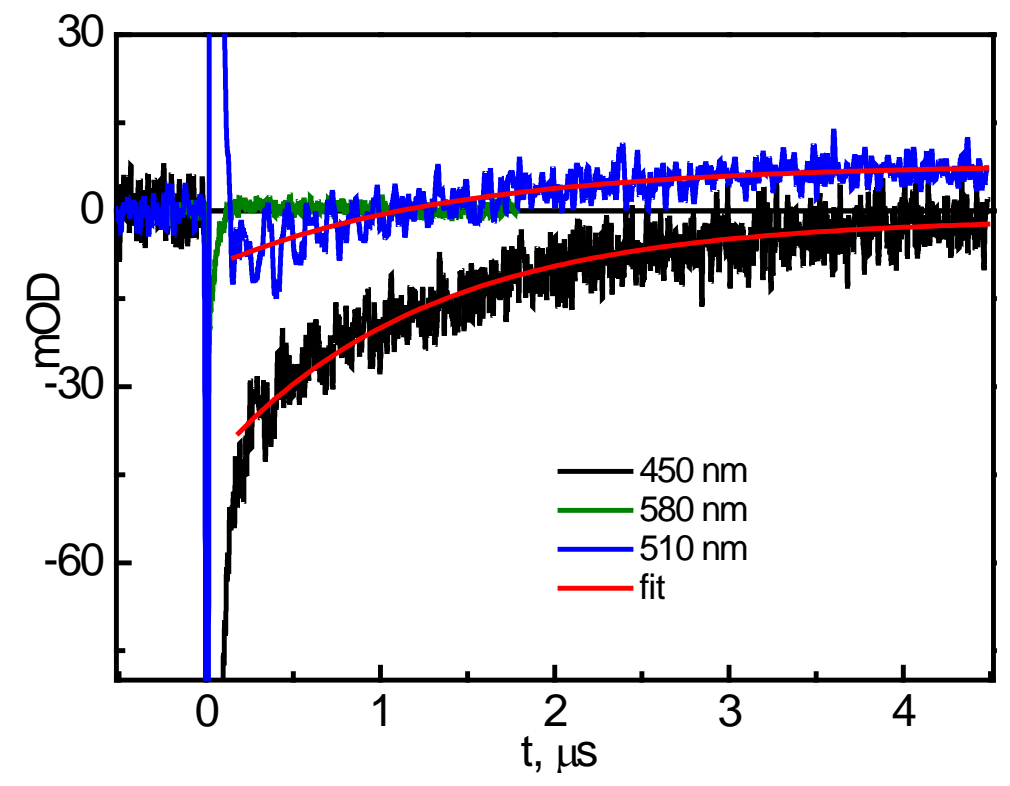

Fig S6. Recovery of the $\left[\mathrm{Ru}^{\mathrm{II}}\right]$ absorption at $450 \mathrm{~nm}$ (black) and concomitant growth of the $510 \mathrm{~nm}$ absorption from $\operatorname{Trp}^{\bullet}$ (blue). The green trace at $580 \mathrm{~nm}$ shows no signal changes after the $\left[{ }^{*} \mathrm{Ru}^{\mathrm{II}}\right.$ ] emission has decayed $(<100 \mathrm{~ns})$. The sample was excited at $532 \mathrm{~nm}$ in $\mathrm{N}_{2}$ saturated $0.5 \mathrm{mM}$ phosphate-borate buffer at $\mathrm{pH} 7.2$ with $40 \mathrm{mM}\left[\mathrm{Ru}\left(\mathrm{NH}_{3}\right)_{6}\right]^{3+}$ as quencher. Red lines show single exponential fits giving $k_{(450 \mathrm{~nm})}=1.1( \pm 0.1) \times 10^{6} \mathrm{~s}^{-1}$ and $k_{(510 \mathrm{~nm})}=$ $8.3( \pm 0.3) \times 10^{5} \mathrm{~s}^{-1}$. 


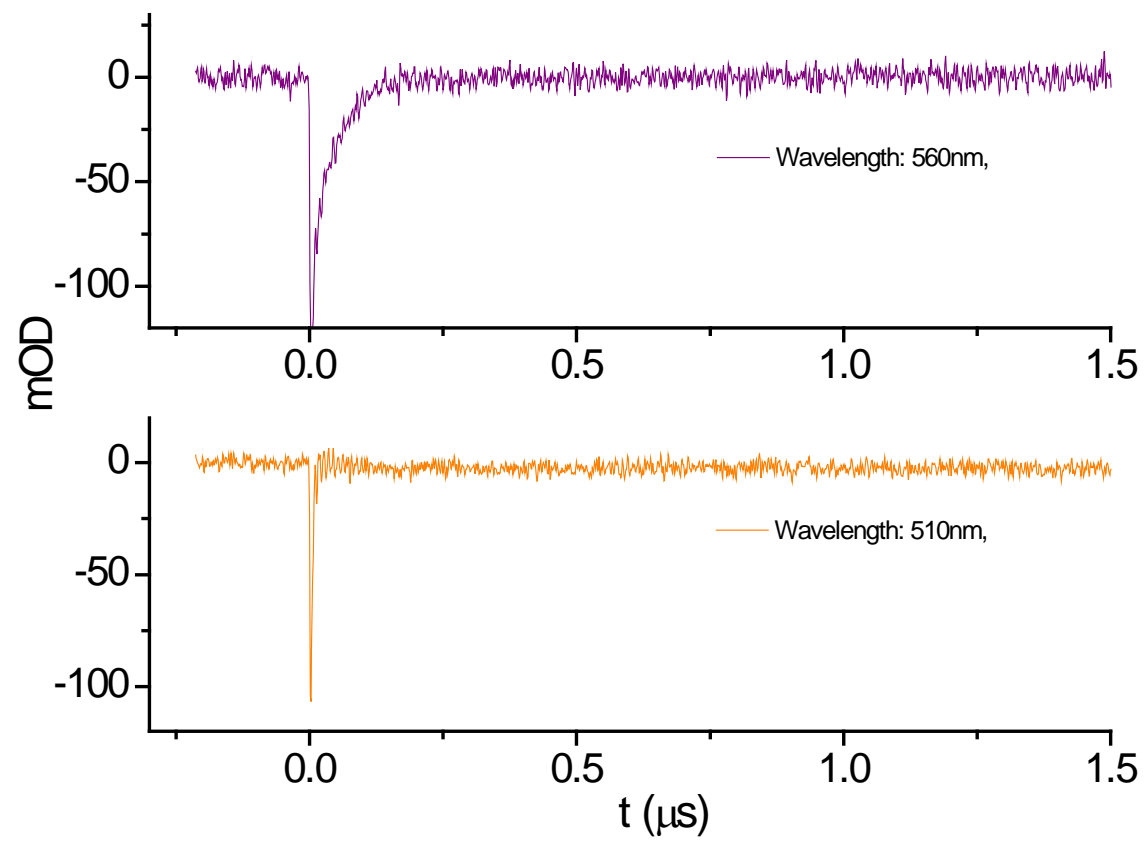

Figure S7. Quenching of $\left[\mathrm{Ru}(\mathrm{bpy})_{3}\right]^{2+}$ upon addition of $40 \mathrm{mM}\left[\mathrm{Ru}\left(\mathrm{NH}_{3}\right)_{6}\right]^{3+}$ as quencher employed in the quenching of linked systems. The decay shows no noticeable spectroscopic signatures for $\operatorname{Trp}^{\bullet}$ or $\operatorname{Trp}^{\bullet} \mathrm{H}^{+}$at $510 \mathrm{~nm}$ and $560 \mathrm{~nm}$, respectively in the absence of any linked tryptophan moiety.

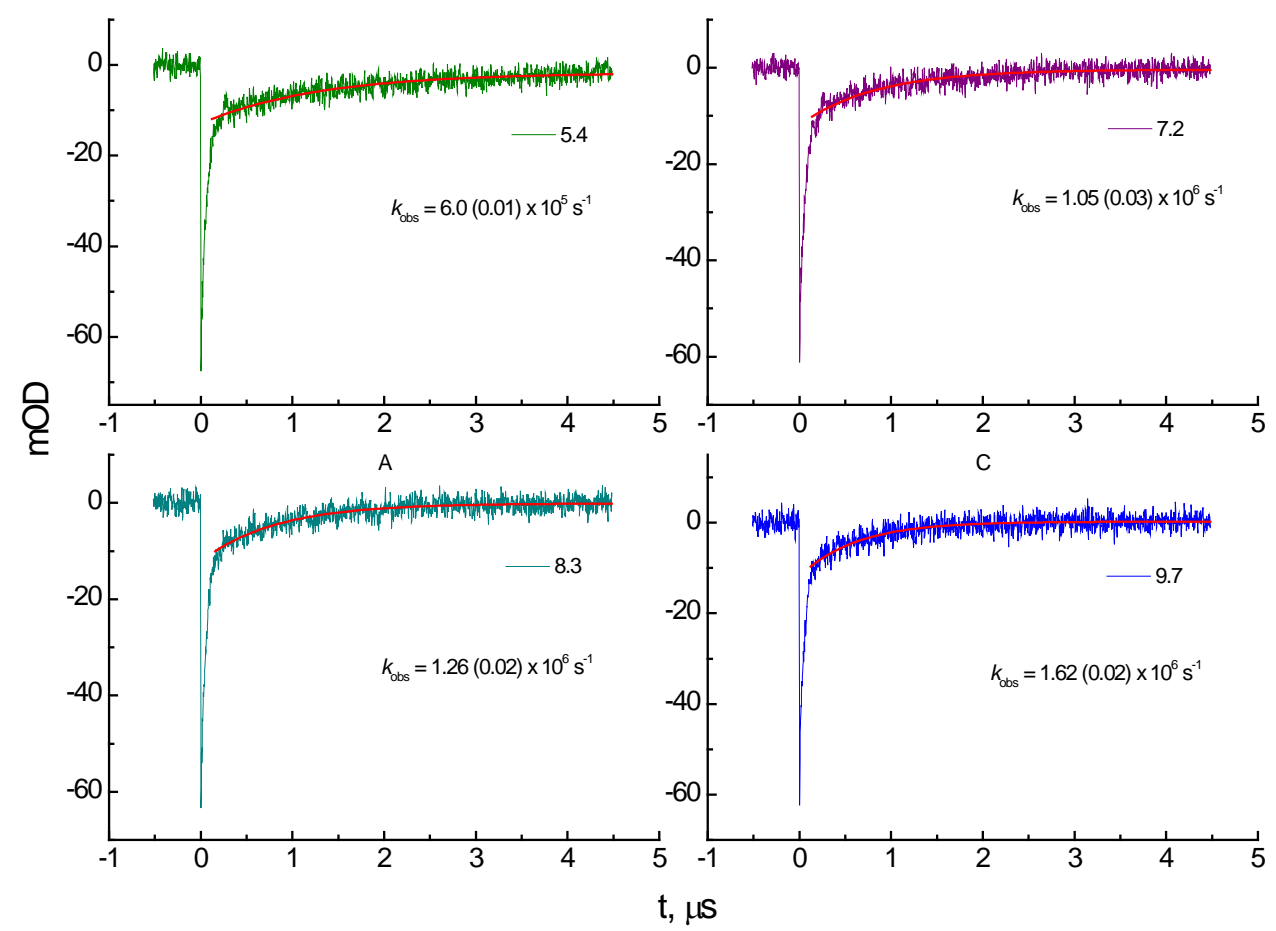

Figure S8. Decay traces of 2 in Phosphate-borate buffer $(0.5 \mathrm{mM})$ with $40 \mathrm{mM}\left[\mathrm{Ru}\left(\mathrm{NH}_{3}\right)_{6}\right]^{3+}$ as quencher at different $\mathrm{pH}$ 's. 
Table S1. First-order rate constants for TrpH-to-[Ru $\left.{ }^{\mathrm{III}}\right]$ electron transfer in complexes $\mathbf{1}$ and $\mathbf{2}$ (determined from the $450 \mathrm{~nm}$ recovery traces) as a function of $\mathrm{pH}$ employed in the construction of fig $4 \mathrm{a}$ ( $\mathrm{k} \pm \mathrm{SD}$ from a fit to a single trace).

\begin{tabular}{|c|c|c|c|}
\hline \multicolumn{2}{|c|}{ Complex 1 } & \multicolumn{2}{c|}{ Complex 2 } \\
\hline $\mathbf{p H}$ & $\boldsymbol{k}_{\mathbf{\text { obs }}} \times \mathbf{1 0}^{\mathbf{6}}, \mathbf{s}^{\mathbf{- 1}}$ & $\mathbf{p H}$ & $\boldsymbol{k}_{\mathbf{\text { obs }}} \times \mathbf{1 0}^{\mathbf{6}}, \mathbf{s}^{\mathbf{- 1}}$ \\
\hline 3.542 & $6.03( \pm 0.14)$ & 5.483 & $0.60( \pm 0.01)$ \\
\hline 3.95 & $6.20( \pm 0.08)$ & 6.022 & $0.64( \pm 0.06)$ \\
\hline 4.64 & $6.11( \pm 0.11)$ & 6.689 & $0.86( \pm 0.04)$ \\
\hline 5.93 & $6.10( \pm 0.17)$ & 7.001 & $1.15( \pm 0.02)$ \\
\hline 6.547 & $6.80( \pm 0.10)$ & 7.24 & $1.05( \pm 0.03)$ \\
\hline 7.23 & $5.72( \pm 0.06)$ & 7.574 & $1.20( \pm 0.02)$ \\
\hline 7.654 & $5.90( \pm 0.08)$ & 7.729 & $1.07( \pm 0.03)$ \\
\hline 8.151 & $6.30( \pm 0.05)$ & 8.03 & $1.23( \pm 0.02)$ \\
\hline 8.303 & $6.0( \pm 0.06)$ & 8.326 & $1.32( \pm 0.02)$ \\
\hline 8.758 & $5.90( \pm 0.10)$ & 9.084 & $1.31( \pm 0.02)$ \\
\hline 8.954 & $6.20( \pm 0.04)$ & 9.322 & $1.35( \pm 0.03)$ \\
\hline 9.10 & $6.09( \pm 0.07)$ & 9.757 & $1.62( \pm 0.021)$ \\
\hline 9.756 & $6.50( \pm 0.07)$ & 10.175 & $2.31( \pm 0.015)$ \\
\hline 10.270 & $9.60( \pm 0.14)$ & 10.532 & $2.91( \pm 0.016)$ \\
\hline 10.654 & $11.4( \pm 0.21)$ & 10.83 & $3.15( \pm 0.04)$ \\
\hline 11.54 & $23.0( \pm 0.20)$ & 11.3 & $5.06( \pm 0.04)$ \\
\hline
\end{tabular}

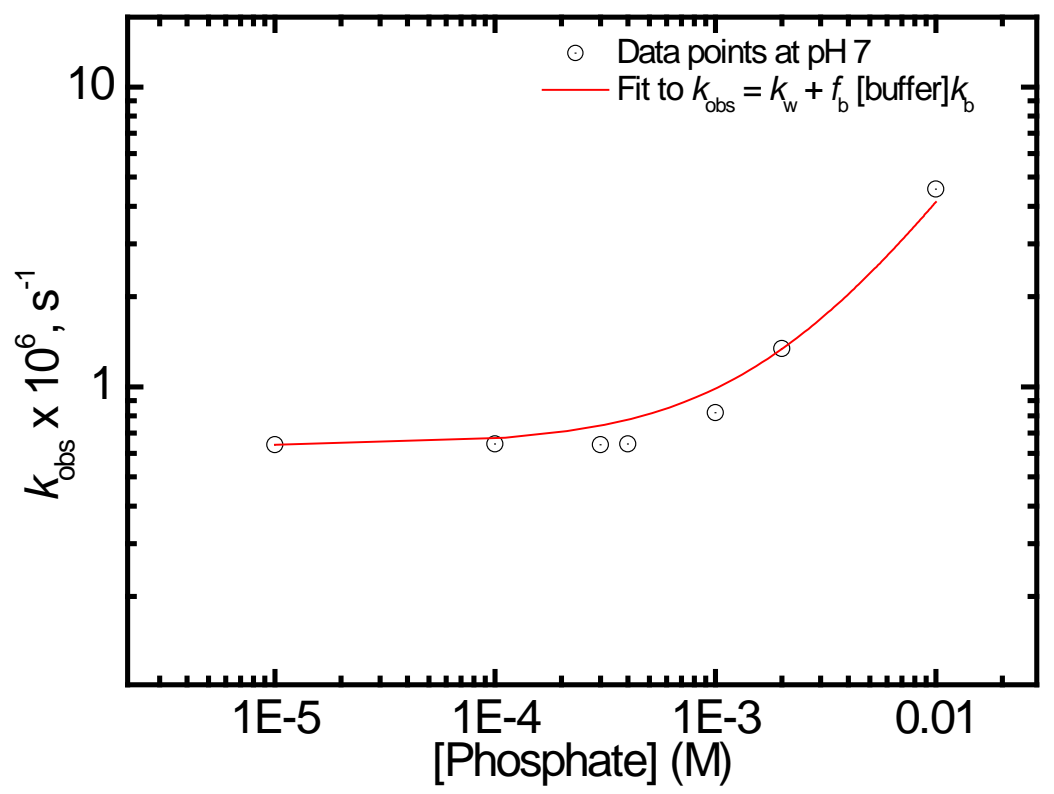

Figure S10. Phosphate buffer dependence of $k_{\mathrm{obs}}$ for 2 and fit to the equation: $k_{\mathrm{obs}}=k_{\mathrm{w}}+f_{\mathrm{b}}$ [buffer] $k_{\mathrm{b}}$ at $\mathrm{pH} 7$. 


\section{Kinetic analysis of a consecutive PTET or ETPT reaction for 2 at neutral pH.}

A PTET reaction can be excluded for the following reasons: The PT step of a PTET reaction from 2 with the available bases is strongly endergonic, as the $\mathrm{pKa}$ of $\operatorname{TrpH}$ is $\sim 17$ and the $\mathrm{pKa}$ values of the conjugate acids for the available bases are much lower: $\mathrm{H}_{2} \mathrm{O}\left(\mathrm{pKa}\left(\mathrm{H}_{3} \mathrm{O}^{+}\right)=0\right)$, $\mathrm{OH}^{-}\left(\mathrm{pKa}\left(\mathrm{H}_{2} \mathrm{O}\right)=14\right), \mathrm{HPO}_{4}{ }^{2-}\left(\mathrm{pKa}\left(\mathrm{H}_{2} \mathrm{PO}_{4}{ }^{-}\right)=7.2\right)$ and $\mathrm{PO}_{4}{ }^{3-}\left(\mathrm{pKa}\left(\mathrm{HPO}_{4}{ }^{2-}\right)=12.4\right)$. The best bases are $\mathrm{OH}^{-}$and $\mathrm{PO}_{4}{ }^{3-}$, but their concentrations at $\mathrm{pH}=7$ are small. With a diffusioncontrolled encounter between $\mathrm{TrpH}$ and base $\left(1 \times 10^{10} \mathrm{M}^{-1} \mathrm{~s}^{-1}\right)$, the rate constant for PT is given by $k_{\mathrm{PT}}=1 \times 10^{10} \times 10^{\Delta \mathrm{p} K \mathrm{a}}$ [base], where $\Delta \mathrm{pKa}=\mathrm{pKa}\left(\mathrm{H}^{+}\right.$base $)-\mathrm{pKa}(\operatorname{TrpH})$. For $\mathrm{OH}^{-}$this results in $k_{\mathrm{PT}} \sim 1 \mathrm{~s}^{-1}$ and for the other bases the value is even lower. Therefore, a PTET reaction is inconsistent with the observed rate constant of $k_{\mathrm{obs}}=1.1 \times 10^{6} \mathrm{~s}^{-1}$ for 2 at $\mathrm{pH}=7$.

An ETPT reaction can be excluded for the because the observed reaction rate constant $k_{\text {obs }}=$ $1.1( \pm 0.1) \times 10^{6} \mathrm{~s}^{-1}$ is close to the one for deprotonation of $\operatorname{Trp}^{\bullet} \mathrm{H}^{+}\left(k_{\mathrm{PT}}=2.5( \pm 0.2) \times 10^{6} \mathrm{~s}^{-1}\right.$ as determined for $\mathbf{1}$ ) and yet there is no observable signal from any intermediate $\operatorname{Trp}^{\bullet} \mathrm{H}^{+}$species. A consecutive reaction $\mathrm{Ru}^{\mathrm{III}}-\operatorname{TrpH}=>\mathrm{Ru}^{\mathrm{II}}-\mathrm{Trp}^{\bullet} \mathrm{H}^{+}=>\mathrm{Ru}^{\mathrm{II}}-\mathrm{Trp}^{\bullet}+\mathrm{H}^{+}$has two kinetic limits.

(a) in a reversible (pre-equilibrium model) case, $k_{o b s}=\frac{k_{E T}}{k_{-E T}} k_{P T}$. Insertion of the experimental values of $k_{\mathrm{obs}}$ and $k_{\mathrm{PT}}$ gives the ratio $\frac{k_{E T}}{k_{-E T}}=0.44$ and consequently that the steady state concentration of $\operatorname{Trp}^{\bullet} \mathrm{H}^{+}$would be $44 \%$ of that for $\left[\mathrm{Ru}^{\mathrm{III}}\right]$. In Figure $3 \mathrm{~b}$ of the main paper, the transient absorption at $450 \mathrm{~nm}$ for the $\mathrm{Ru}^{\mathrm{III}}$ species after $0.5 \mu \mathrm{s}$ is $-30 \mathrm{mOD}$. Taking the difference in extinction coefficients into account $\left(\Delta \varepsilon_{580}\left(\operatorname{Trp}{ }^{\bullet} \mathrm{H}^{+}\right) / \Delta \varepsilon_{450}\left(\mathrm{Ru}^{\mathrm{III}}\right)=-\right.$ 0.30 , see main paper), the absorption at $580 \mathrm{~nm}$ for the Trp ${ }^{\bullet} \mathrm{H}^{+}$species would be $4 \mathrm{mOD}$ at the same time point, and this signal would have decayed in parallel to the $450 \mathrm{~nm}$ rise. This is clearly not the case, as the $580 \mathrm{~nm}$ trace lies $<1 \mathrm{mOD}$ during the entire reaction.

(b) for ETPT with an irreversible ET step, consecutive kinetics (see any physical chemistry textbook) gives the maximum concentration of the intermediate as a fraction of the initial $\left[\mathrm{Ru}^{\mathrm{III}}\right]$ or final $\left[\operatorname{Trp}^{\bullet}\right]$ :

$$
\frac{\left[\operatorname{Trp}{ }^{\cdot} \mathrm{H}^{+}\right]_{\max }}{\left[R u^{I I I}\right]_{0}}=\left(\frac{k_{E T}}{k_{P T}}\right)^{\left(\frac{k_{P T}}{k_{P T}-k_{E T}}\right)}
$$

which occurs at a time

$$
t_{\max }=\frac{1}{k_{E T}-k_{P T}} \ln \left(\frac{k_{E T}}{k_{P T}}\right)
$$

Insertion of values, assuming $k_{\mathrm{ET}}=k_{\mathrm{obs}}$, and $\left[\mathrm{Ru}^{\mathrm{III}}\right]_{\max }=35 \mathrm{mOD}$ in Figure $3 \mathrm{~b}$, gives $\frac{\left[\mathrm{Trp}^{*} \mathrm{H}^{+}\right]_{\max }}{\left[\mathrm{Ru}^{I I I}\right]_{0}}=0.23$ at $t_{\max }=0.6 \mu \mathrm{s}$. Again taking the differences in extinction coefficients into account, this would mean that the $580 \mathrm{~nm}$ trace would rise to a maximum of $3 \mathrm{mOD}$ after $=$ $0.6 \mu$ s, followed by a decay. This is clearly not the case, as the $580 \mathrm{~nm}$ trace lies $<1 \mathrm{mOD}$ during the entire reaction. 


\section{References}

S1. Sjödin, M.; Styring, S.; Wolpher, H.; Xu, Y.; Sun, L.; Hammarström, L. J. Am. Chem. Soc. 2005, 127, 3855.

S2. Ghanem, R.; Xu, Y.; Pan, J.; Hoffman, T.; Andersson, J.; Polivka, T.; Pascher, T.; Styring, S.; Sun, L.; Sundström, V. Inorg. Chem.2002, 41, 6258.

S3. Zhang, M.-T.; Hammarström, L. J. Am. Chem. Soc. 2011, 133, 8806.

S4. Glasoe, P. K. and F. A. Long. J. Phys. Chem. 1960, 64, 188-190. 